\title{
Belangrike meta-teoretiese riglyne betreffende die emosioneel verwonde persoon
}

Authors:
Wentzel C. Coetzer ${ }^{1}$
Lutricia Snell ${ }^{1}$
Affiliations:
'Department of Practical
Theology, North-West
University, Potchefstroom
Campus, South Africa
Correspondence to:
Wentzel Coetzer
Email:
wentzelcoetzer@telkomsa.
net
Postal address:
PO Box 19320, Noordbrug
2522, South Africa
Dates:
Received: 26 July 2011
Accepted: 22 Feb. 2012
Published: 26 Apr. 2012
How to cite this article:
Coetzer, W.C. \& Snell,
L., 2012, 'Belangrike
meta-teoretiese riglyne
betreffende die emosioneel
verwonde persoon', Verbum
et Ecclesia 33(1), Art. \#574,
org/10.4102/ve.v33i1.574

(C) 2012. The Authors. Licensee: AOSIS OpenJournals. This work is licensed under the Creative Commons Attribution License.
Important meta-theoretical guidelines regarding the emotionally wounded person. This article examines the relationship between emotional woundedness and faith estrangement. Trust issues towards God often emerge in the heart of the believer when left vulnerable and in shock due to unforeseen trauma. The dilemma is that this condition leaves the wounded person more vulnerable. With a view to bringing healing and deeper faith, different trauma intervention models are evaluated and the role of forgiveness, retribution and faith are examined. In conclusion, some guidelines regarding a holistic approach in the pastoral counselling of the traumatised faith-estranged person are presented.

\section{Inleiding}

Metateorie verskaf die wetenskaplike vertrekpunte wat raakvlakke deel met ander vakke wat aspekte van dieselfde werklikheidsveld ondersoek (Venter 1996:89). Pieterse (1993:133) stel dat die basisteorie gevoed word deur interdissiplinêre gesprekke met ander teologiese dissiplines en met insigte vanuit die grenswetenskappe, asook met insigte vanuit empiriese ondersoeke in die praktiese teologie. Metateorie verhelder en belig dan die basisteorie vanuit grenswetenskappe. Die integrasie van metateoretiese insigte vervul ' $n$ belangrike rol ten einde 'n praktykteorie te ontwerp (Heystek 2000:56). Teen hierdie teoretiese agtergrond word in hierdie artikel gefokus op enkele metateoretiese merkers wat genesing van die verwonde geloofsvervreemde kan meebring.

\section{Probleemstelling}

Praktiese Teologie word binne die konteks van die veranderende samelewing genoop om voortdurend op 'n dinamiese wyse relevansie te behou met betrekking tot die mens in konteks, sy vraagstukke en eksistensiële krisisse, ten einde pastoraal daarby aansluiting te vind. In die ingrype met die verwonde geloofsvervreemde word dikwels slegs op die psigiese wond gefokus, en vind volkome genesing nie plaas aangesien daar nie noodwendig altyd ook op die geestelike wond gefokus word nie. Onlangse navorsing dui daarop dat godsdienstige praktyke in die algemeen ' $n$ integrale deel van die benadering tot spanningsvolle situasies vorm, maar dat traumatiese gebeure ' $n$ negatiewe impak het op godsdienstige persepsies en praktyke (Falsetti, Resick \& Davis 2003:392). Donahue (1985:400-419) is van mening dat godsdienstige belewenisse deur 'n traumatiese insident beïnvloed word, wat daartoe kan lei dat die impak van die gebeure, as gevolg van verlies van die godsdienstige verwysingsraamwerk, mag intensifieer en meer skade berokken. Volgens Herman (2001:51-52) ondermyn sodanige gebeure die geloofsisteme van die slagoffer. Sekere studies handhaaf ook die veronderstelling dat die simptome van posttraumatiese stressindroom in sekere gevalle die gevolg mag wees van botsende geloofsisteme (Decker 1993:15-32), en dat posttraumatiese stressindroom dan in sulke gevalle ook as 'n geestelike wond benader hoort te word (Klevberg 2005:1). In hierdie opsig is die geloofsvervreemde uiteraard baie kwesbaar aangesien daar ' $n$ gebrek aan beide geestelike ankers en 'n geestelike ondersteuningstruktuur bestaan.

\section{Doelstelling en Metodologie}

Hierdie artikel het ten doel om ondersoek in te stel na die mate waartoe perspektiewe vanuit die wetenskappe soos psigologie, psigiatrie en die mediese wetenskap kan bydra tot begrip van wat trauma is, asook die herstel van die verwonde geloofsvervreemde. 'n Pastoraal psigologiese benadering sal gevolg word. Telkens waar daar in die artikel verwys word na hy en/of hom sluit dit outomaties ook in sy en/of haar. Metateoretiese aspekte wat ondersoek word in hierdie artikel sluit in tipering van trauma, metateoretiese beskouinge van genesing, die behandeling van die emosioneel verwonde, die rol van vergifnis, gevolgtrekkings en aanbevelings.

\section{Verduideliking van Terminologie}

Die term 'trauma' is afgelei van die Griekse term trauma wat op 'verwonding' dui (Matsakis 1996:17). Die literatuur verwys in talle gevalle na fisiese en emosionele trauma as verwonding 
(Coetzer 2006:12-22; Klevberg 2005:1; Herman 2001:119). 'n Duidelike onderskeid word in die literatuur getref tussen akute trauma, klassieke posttraumatiese stresversteuring (hierna na verwys as PTSV), en gekompliseerde PTSV (Kaplan \& Kaplan 2007:614-618; Williams \& Sommer 2002:33; Wright 2003:222). In hierdie artikel sal slegs die term 'trauma' gebruik word.

\section{Genesing (heling) Wat is genesing?}

Die Wêreldgesondheidsorganisasie (WGO) definieer geestesgesondheid as 'a state of well-being in which every individual realizes his potential, copes with the stresses of life, works productively, and is able to make a contribution to his community' (World Health Organisation 2007:1). Die SuidAfrikaanse Federasie vir Geestesgesondheid (SA Federation for Mental Health 2006:1) kenmerk drie eienskappe van die geestesgesonde, naamlik gemak met die self, met andere asook die konstruktiewe hantering van eie emosies.

Foa, Chrestman en Gilboa-Schechtman (2008) stel die volgende metafoor voor as ' $n$ toepaslike omskrywing van die doel van heling ten opsigte van die getraumatiseerde:

The traumatic experience is kept in your memory like a book. You are trying to keep this book closed and never read it. But the book opens by itself, suddenly and unexpectedly, on different pages, and you find yourself "reading" scary parts against your will. Our goal is to help you read this book from beginning to end several times until we manage to put some order into the pages. As a result, in the future, you will be able to open the book on whatever page you want, read it, browse through it, or just leave it closed, not out of fear but out of boredom. (p. 125)

\section{Heling (genesing) Wat is heling?}

Die pastoraal sielkundige aard van hierdie studie noodsaak die verdere eksplorasie van die begrip van genesing of heling.

Die Skrif (Rom 3:23, Rom 8:29; 2 Kor 12:7-9) se gegewe en Puffer (2007:47-53) se aannames van menslike wesens (in aansluiting by die Skrif) as '... fashioned into God's image ... fallen with a sinful nature ... striving to find meaning, ... redeemable, dwellable by God's Spirit, ... transformable for God's purposes ...' lei tot die volgende definisie van 'heling':

'n Geestesproses waartydens die individu die heil in Christus aanvaar, eie identiteit in Christus omhels, toenemend geestelik kan begin onderskei tussen emosionele lyding weens menswees in 'n gevalle toestand op aarde en lyding weens ongehoorsaamheid aan God se Skrifgebaseerde morele wette, normale lewensdruk as deel van geestelike groei onder leiding van die Gees begin hanteer, en 'n Christus-geïnspireerde bydrae tot die eie werkkring asook die breër samelewing begin lewer. (L. Schnell, 2de outeur, se definisie)

\section{Genesing van die verwonde}

Die welslae van die genesingsproses hou direk verband met die ontwikkelingsfase waartydens die trauma ervaar is. Die stadium waartydens die psige as gevolg van die trauma as't ware 'vasgevries' het, vorm die sleutel tot die terapeutiese invalshoek met die oog op die ontknoping van die trauma en uiteindelike genesing van die verwonding (Herman 1997:156; Sweeney 2011:1).

\section{Vertrekpunte in trauma behandeling}

As kenner, navorser en praktyk spesialis op die gebied van die behandeling van trauma word Sweeney (2011:1) se vertrekpunte tydens die aanvang van die behandelingsproses eksploreer in hierdie afdeling. Volgens Sweeney sluit die vertrekpunte die volgende in:

- trauma verander die persoon vir altyd

- trauma verander tot 'n groot mate die persoon se hanteringvermoëns

- trauma inhibeer en beperk verdere ontwikkeling.

\section{Doelwitte in trauma behandeling}

Volgens Sweeney (2011:1) sluit doelwitte van toepassing tydens trauma behandeling in die verlening van hoop asook die voorsiening van 'n veilige proses van herstellende genesing in.

\section{Doelwitbeginsels in die behandeling van trauma}

Sweeney (2011:1) het die volgende waardevolle terapeutiese beginsels vir die behandeling van die verwonde ontwikkel:

- Trauma oorskrei persoonlike ruimte en grense. Ter voorkoming van verdere minagting van die individu se grense, is behandeling van trauma doeltreffend indien die verwonde toegelaat word om traumatiese gebeure vryelik te eksploreer en prosesseer, sodat genesing en groei as doelwit bevorder word. Die terapeut se modellering van begrensing kommunikeer onder andere respek. Dit bevat ' $n$ verdere terapeutiese genesingsaspek deurdat die verwonde hul eie menswaardigheid deur hierdie ervaring begin terugvind.

- Teen die agtergrond van die terapeutiese verhoudingsraamwerk baat die verwonde by die ervaring van die opbou van 'n veilige, toepaslike en bevestigende verhouding met 'n vertrouenswaardige helper. Die terapeut se selfbewussyn en selfhandhawing tydens die opbou van die vertrouensverhouding vorm deel van die genesingsproses en die uiteindelike psigiese herstel van die verwonde.

- Trauma as aktiwiteit is geforseer. Terapie behoort daarom fasiliterend en nie voorskriftelik te wees nie. Getraumatiseerdes word dikwels geforseer om iets soos mishandeling geheim te hou en gevolglik moet die terapeut bewustelik ingestel wees op die toelating en bevordering van selfuitdrukking. Bemagtiging en genesing word hierdeur bevorder.

- Waar trauma dikwels binne die gesinskonteks geskied, is gesinsterapie binne die sisteembenadering as toepaslikste metode ' $n$ wesenlike deel van terapie.

- Verwondes mag bisarre verdedigingsmeganismes inspan. Terapeuties behoort die verwonde nie totaal gestroop te 
word daarvan nie, maar begelei te word tot meer gesonde wyses van uitdrukking.

- Behandeling moet 'n kontinuum van aspekte hanteer, insluitende die psigiese, kognitiewe, fisiese en geestelike dimensies. Trauma mag skade aan een of elk van hierdie areas aangerig het.

- 'n Multidissiplinêre holistiese benadering is noodsaaklik ter maksimale aanvulling van die hulpverlening deur die terapeut.

- Deurlopende assessering is noodsaaklik, weens die ontwikkelende proses in terapie en ontwikkelende veranderinge in die beradene.

- Veral seksueel verwondes toon bewyse van verwronge en beskadigde grense. Hulle mag baat by die aanleer van vaardighede om in enige situasies hulself te kan handhaaf. Groepwerk en psigo-opvoedkundige werk word gewoonlik in sulke gevalle aanbeveel.

- Traumabehandeling verg tyd. Dit is onrealisties, onredelik en waarskynlik oneties om verwagtinge by die verwonde te skep dat jare lange trauma sigself sal genees binne ses tot agt sessies.

\section{Die proses van genesing}

Matsakis (1996:143) som die proses van genesing as volg op:

- Die kognitiewe stadium: die onthou van die trauma.

- Die emosionele stadium: hernude ervaring van gevoelens geassosieer met die trauma.

- Die bemagtigingsfase: die verwonde vind betekenis in sy trauma en ' $n$ oorlewingsingesteldheid en identiteit geassosieer met oorwinning. Herman (1997:156) beklemtoon dat trauma verskillend benader moet word tydens die onderskeie fases van die helingsproses. In hierdie verband gee sy 'n opsomming van die helingsproses en terapeutiese benadering gekoppel aan die tipe trauma (Tabel 1).

\section{Behandelings modelle vir trauma}

Modelle ontwerp vir die behandeling van traumaslagoffers, fokus gewoonlik op die aard daarvan, die fase waartydens dit plaasgevind het asook die graad van die trauma. Daar sal vervolgens gefokus word op enkele van die belangrikste benaderings met betrekking tot die behandeling van trauma.

\section{Kognitiewe gedragsterapie}

Die getraumatiseerde is tipies selfverwytend, het 'n lae selfbeeld en is dikwels gefikseer op die negatiewe. Kognitiewe ingrype behels die begeleide herevaluering van negatiewe selfpersepsies en selfopvattinge, asook andere en die omgewing wat vanuit die trauma ontstaan het. Soos hierdie negatiewe aannames herevalueer word, ontwikkel daar dikwels ' $n$ meer positiewe model oor die self en andere, terwyl die getraumatiseerde ' $n$ meer gedetailleerde en saamgestelde insig oor die traumatiese gebeure verkry (Foa, Chrestman \& Gilboa-Schechtman 2008:109). Volgens Monson en Friedman (2006:1-13) verteenwoordig kognitiewe gedragsterapie vir trauma ' $n$ breë klas van terapieë wat almal die volgende doelwitte beklemtoon:

- waarneembare uitkomste

- simptoom verligting

- doelgerigte ingrype

- die verwagting dat die respondent 'n aktiewe rol sal speel in die helingsproses.

Uit 'n kognitiewe gedragsterapieperspektief word menslike ervarings beskou as die produk van vier interaktiewe elemente naamlik fisiologie, kognisie, gedrag en emosies (Scott \& Stradling 2006:40). Daar bestaan verskeie uitgangspunte ten opsigte van die toepassing van kognitiewe gedragsterapie binne die konteks van trauma. Onder andere word die volgende benaderings gehuldig.

\section{Stres-inokuleringsopleiding}

Hier word die getraumatiseerde toegerus met tegnieke om die negatiewe psigologiese effekte van trauma te kan hanteer. Hierdie tegnieke was aanvanklik voorgestel deur Meichenbaum (1977:143). Dit behels die aanleer van asemhalings- en spierontspanningstegnieke in 'n poging om te ontspan, en die ontwikkeling van kognitiewe hanteringsmeganismes. Hierdie tegnieke het ten doel om gedagtes van bedreiging en katastrofe teë te werk in omstandighede wat sou kon aanleiding gee tot fobiese assosiasie met die trauma.

\section{Blootstellingsterapie}

Dit is ' $n$ behandelingsprotokol wat daarop gemik is om die getraumatiseerde te help om die traumaverwante situasies, herinneringe, gedagtes en gevoelens te oorbrug deur die in vivo- en veronderstelde blootstelling. As blootstellingsterapie behels in vivoblootstelling herhaaldelike, langdurige blootstelling aan objektiewe, veilige situasies wat vermy word weens traumaverwante angs. PTSV-simptome soos vlug en vermyding word deur hierdie kognitiewe modifikasies verlaag, en premorbiede funksionering geleidelik maksimaal herstel. As kognitiewe strategie vind in vivoblootstelling aan omgewingsfaktore geassosieer met byvoorbeeld verkragtings trauma (waar reuke, klanke en

TABEL 1: Fases van herstel.

\begin{tabular}{|c|c|c|c|}
\hline Tipe sindroom & Fase 1 & Fase 2 & Fase 3 \\
\hline Histerie & $\begin{array}{l}\text { Stabilisering en simptoomgeoriënteerde } \\
\text { behandeling }\end{array}$ & Verkenning van trauma geheue & Persoonlikheidsherintegrasie en -herstel \\
\hline Gevegstrauma & Vertroue, opvoeding, stresbestuur & Trauma word herleef & Integrering van trauma ondervinding \\
\hline $\begin{array}{l}\text { Gekompliseerde posttraumatiese } \\
\text { stressindroom }\end{array}$ & Stabilisering & Integrasie van geheue & Selfontwikkeling, integrasie \\
\hline Meervoudige persoonlikheidsversteurings & $\begin{array}{l}\text { Diagnose, stabilisering, kommunikasie, } \\
\text { samewerking }\end{array}$ & Trauma verwerking & $\begin{array}{l}\text { Resolusie, integrering, ontwikkeling van } \\
\text { postresolusie hanteringsmeganismes }\end{array}$ \\
\hline Traumatiese versteurings & Veiligheid & Herinnering en rou & Herkonnektering \\
\hline
\end{tabular}


lokaliteit byvoorbeeld baie prominent figureer) plaas, nadat die trauma emosioneel geprosesseer is (Foa \& Rothbaum 1998:144).

\section{Kognitiewe herstrukturering}

Hier word die getraumatiseerde geassisteer om alternatiewe beskouings van die traumatiese gebeurtenis te ontwikkel. Die individu word aangemoedig om te praat oor die herinneringe aan die gebeurtenis en hierdie gedagtes word bevraagteken en vervang met ' $n$ meer gebalanseerde en rasionele beskouing van die trauma.

Carroll en Foy (1992:61) fokus in hierdie verband hoofsaaklik op die gestruktureerde toepassing van kognitiewe herstrukturering van die verwonde se wêreldbeeld. Deur middel van die eksplisiete hersiening van die verwonde se basiese veronderstellings omtrent die lewe voor en na die trauma, word die persoon bemagtig deur die bevestiging van hierdie fundamentele aannames en wen hy veld met die keuse tot die moderering van ekstreme reaksies ten gunste van 'n meer gebalanseerde perspektief. Die terapeutiese rol is bloot die begeleiding van die verwonde tot die ontdekking van hierdie implisiete aannames, wat dit dan eksplisiet maak, terwyl dit die potensiaal tot wysiginge daaraan inhou.

\section{Oogbeweging desensitisering- en herprosesseringsterapie (EMDR)}

Oogbeweging desensitisering- en herprosesseringsterapie (algemeen bekend in Engels as EMDR - Eye movement desensitisation and reprocessing therapy) is ' $n$ meer onlangs ontwikkelde metode in die behandeling van trauma. Die benadering is aanvanklik voorgestel deur Shapiro (1989:199223). Die terapie behels dat die getraumatiseerde sy ooglede ritmies beweeg terwyl die traumatiese gebeure en beelde in herinnering geroep word. Die benadering poog om die negatiewe emosies, gedagtes en herinneringe wat verband hou met die traumatiese insident te ontsluit en dan deur die brein te laat prosesseer. Hierdie metode is reeds met groot welslae by oorlogsveterane aangewend (Hatter 2007:2-5). Daar bestaan 'n verskeidenheid van opinies oor die waarde van hierdie benadering. Kaplan en Kaplan (2007:621) beveel die metode aan as effektief in die behandeling van beide akute en kroniese PTSV. Navorsers soos Foa, Keane en Friedman (2000:298) en Chambless et al. (1998:9) beveel EMDR aan as effektief in die behandeling van PTSV vir sekere beperkte toepassings. Ander navorsers waarsku teen die algemene aanvaarding van die effektiwiteit van dié benadering (Wilson, Friedman \& Lindly 2001:149). Robinson (2006:266) beveel aan dat empiries gefundeerde kognitiewe gedragsterapie benaderings bo hierdie metode gekies behoort te word vir slagoffers van fisiese trauma.

\section{Kort termyn videogebaseerde trauma terapie}

Volgens Williams en Sommer (2002:106-108) is korttermyn videogebaseerde traumaterapie effektief met verwondes met klassieke Tipe 1 en gekompliseerde Tipe 2 trauma. Die stappe van hul kernbehandelingsmodule is soos volg.
Traumawerk: Daar word gefokus op 'n gevallegeskiedenis via ' $\mathrm{n}$ narratiewe benadering, asook kunsterapie. Toegang tot die traumaherinnering is beide verbaal en nieverbaal via beelde en tekeninge. Die narratief word prosesseer binne ' $n$ negentig minute-sessie. ' $n$ Bandopname word gemaak van die sessie, wat 'n paar dae later tydens hersiening weer op band of $C D$ geneem word in die teenwoordigheid van die terapeut. Uitbreidinge op die narratief word op rekord geneem. Hierdie band of $\mathrm{CD}$ dien as huiswerk vir die verwonde, ten einde ten volle te identifiseer met die narratief as eie persoonlike geskiedenis. Tydens hierdie twee sessies word deurgaans geëksploreer of daar enige vorige trauma plaasgevind het. Die tweede sessie behoort binne 4-5 dae na die aanvang van die traumawerk plaas te vind. Indien meer tyd tussen die eerste en tweede sessies verloop, is die verwonde geneig om angs op te bou rakende die trauma. Die hersiening van die eerste sessie verskaf ' $n$ behoudende omgewing vir moontlike angs.

DVD dialoog: Hierdie fase duur 2-4 sessies. Die oogmerk hiertydens is om te verseker dat enige traumatiese gedissosieerde selfstaat wel bevry is van die traumatiese belewenis wat tevore vasgevries in tyd voorgekom het.

Gefokusde DVD terapie: Hierdie fase is gemik daarop om die slagoffermitologie op te los. Die taak is om 'n opname met ' $n$ beskrywing van die traumagedrewe aannames van die self as beskadig en die wêreld as gevaarlik, te maak. Die verwonde se bestudering van hierdie opname as huiswerk, los heel dikwels hierdie mitologie op.

Hierdie kernmodule word binne een week van 'n intensiewe buitepasiënteprogram voltooi, met vier tot ses daagliks geskeduleerde sessies. In geval van veelvuldige traumas word by preverbale traumas begin via kunsterapie en word daar tydens die proses op herroepte beelde gefokus. Nadat al die traumawerk voltooi is, word dissosiasie en gespletenheid binne ses sessies hanteer (in geval van komplekse PTSV) en opgelos via DVD dialoog.

Opsommend is die hoofelement in genesing van beide Tipe 1 en Tipe 2 trauma die erkenning van die futiliteit van ' $n$ leefwyse gebaseer op slagoffermitologie. Hierop volg die ontmaskering van die 'mitologie' deur herhaalde ontdekkings dat hierdie leefwyse gedoem is tot mislukking. Hierdie ontmaskering van die slagoffermitologie vind tuis plaas as die verwonde DVD opnames van die behandelingsessies bestudeer, en dit ook geleentheid vir objektiewe selfkonfrontasie bevorder. Slegs na die suksesvolle afloop van bovermelde proses kan 'n nuwe lewenswyse ontwikkel.

Psigodinamiese psigoterapie: Kaplan en Kaplan (2007:620621) beskou die psigodinamiese benadering as effektief met PTSV-pasiënte indien implementering geïndividualiseer word aangesien die herleef van die traumatiese gebeure sekere persone mag oorweldig. Die korttermyn kognitiewe benadering in hierdie model voorkom die risiko vir afhanklikheid en langdurige terapie, hoewel aspekte wat insluit agterdog, paranoia, vertroue, en samewerking 
negatief raak. Psigoterapie na 'n traumatiese gebeure volg die krisis-ingrype model, met die klem op ondersteuning, opvoeding en die ontwikkeling van hanteringsmeganismes en aanvaarding van die gebeure. Nadat PTSV ontwikkel het, word daar oor die algemeen twee benaderings gevolg: blootstellingsterapie wat sistematiese desensitisering behels, en streshanteringsvaardighede wat ontspanningstegnieke en kognitiewe benaderings tot die trauma impliseer. Blootstellingsterapie toon meer standhoudende resultate op die langtermyn, teenoor die korttermyn voordele wat die ontspanningstegnieke inhou.

Psigodinamiese psigoterapie fokus op die dinamika in die onderbewussyn en beskou dit as 'n belangrike rolspeler betreffende emosies en gedrag. Volgens hierdie benadering word bewustelike gedagtes, gevoelens en gedrag gevorm deur prosesse in die onderbewussyn wat verband hou met onder andere impulse, fantasieë, konflikte en ondervindings uit die verlede. Om 'n verandering in gedrag te bewerkstellig, moet daar deur hierdie gevoelens gewerk word (Matthews \& Chu 1997:317). Navorsers verskil betreffende die effektiwiteit van hierdie benadering. Leichsenring et al. (2009:875881) vergelyk die doelmatigheid van die psigodinamiese benadering met dié van kognitiewe gedragsterapie soos van toepassing op algemene angssteurnis. Volgens Foa en Rothbaum (1998:40) is die effektiwiteit van die benadering nog nie wyd genoeg getoets in gekontroleerde studies nie. Wethington et al. (2008:296) is van mening dat daar onvoldoende bewyse bestaan dat psigodinamiese terapie effektief is in die behandeling van PTSV by kinders en adolessente.

Farmakologiese Terapie: Spesifieke voorskrifmedikasie word met effektiwiteit vir PTSV gebruik deur psigiaters. Serotienheropname-inhibeerders (SSRI's) word aanbeveel vir die vermindering van die simptome van PTSV, hoofsaaklik weens hul doeltreffendheid, toleransie en veiligheid. Die beste resultate is gekoppel aan behandeling van ' $n$ jaarlange duur. Sekere studies dui aan dat SSRI's simptome van depressie, angs en hiperbedagtheid met groot welslae behandel. Vermyding, ontkenning en emosionele gevoelloosheid reageer met ' $n$ mindere mate van sukses op hierdie behandeling (Kaplan \& Kaplan 2007:621).

\section{Die getraumatiseerde en vergifnis}

Die gebruik van vergifnis as ' $n$ hulpmiddel in terapeutiese ingrype is ' $n$ relatief nuwe area van navorsing. In die afgelope twee dekades is daar begin met empiriese ondersoeke na die nut van vergifnis in ' $n$ terapeutiese konteks. Sodanige ondersoeke se slotsom is dat vergifnis ' $n$ betekenisvolle bydrae kan maak tot die genesing van gebroke verhoudinge. Al-Mabuk, Enright en Cardis (1995:427-444) se gevolgtrekking is dat die verwonde se indiepte beskouing van die oortreder se menswees kan lei tot erbarming en empatie, wat die sleutels bied tot genesing. Daar is breë konsensus in die literatuur dat vergifnis ' $n$ belangrike terapeutiese ingrype behoort te wees ter nastrewing van die doelwit van heling van interpersoonlike verhoudinge (Ferch
1998:261; Murray 2002:188; Denton \& Martin 1998:281; Lynch 1985:105; Worthington 2003:26).

\section{Aspekte uitgesluit deur vergifnis}

Volgens Borris (2003:10) en Kotze (2008:84) sluit vergifnis spesifieke aspekte uit. Hieronder sluit hul begenadiging en kwytskelding in, aangesien vergifnis nie noodwendig impliseer dat die straf vir die daad van verwonding versaak word nie. Vergifnis is ' $n$ interne bevrydende proses, terwyl begenadiging ' $n$ openbare handeling behels. Louw (2000:464, 412-415) koppel vergifnis aan bevryding, vrede, verligting en 'n konkrete belewenis van God se Koninkryk in emosies en gedagtes. Verder is versoening nie 'n element van vergifnis nie, aangesien vergifnis die interne proses van een persoon is. Kotze (2008:84) is van mening dat vergifnis ook ontkenning, selfblaam, geldingsdrang ('lack of assertiveness') en vergetelheid uitsluit aangesien hierdie aspekte veel eerder verband hou met die pyn en onregpleging, terwyl vergifnis tekenend is van moed, karakter en daadkrag om die realiteit daarvan te erken en daarmee te handel. Louw (2000:413) stem saam dat dit ' $n$ bewustelike besluit en ook proses is.

Nogtans word die begeleiding tot die agape-liefde in die literatuur voorgestaan as Skrifstandaard in die lig van die transformerende krag van die Heilige Gees (Ef 5:18). Die Skrif plaas klem op realistiese pogings tot versoening (Matt 5:23; Ef 4:32). Tan (2011:316) verwys veral na die navorsing van beide Worthington (2003) en Hargrave (1994) in hierdie verband.

\section{Die proses van vergifnis \\ 'n Definisie}

Thompson et al. (2005) definieer vergifnis as volg:

Forgiveness is the framing of a perceived transgression such that one's responses to the transgressor, transgression, and sequelae of the transgression are transformed from negative to neutral or positive. The source of a transgression, and therefore the object of forgiveness, may be oneself, another person, or a situation that one views as being beyond control. (p. 318)

Beide Arterburn (2005:120-145) en Borris (2003:11) beskryf die proses van vergifnis as 'n keuse, 'n eiening van die pyn en die aanvaarding van verantwoordelikheid vir die afhandeling van spesifieke sielkundige stappe oor 'n tydperk, afhanklik van faktore soos die intensiteit en geskiedenis van die oortreding. Hierdie proses kan op verskillende fases 'n aanvang neem, afhangende van die omstandigheid en trauma betrokke.

\section{Die proses per se}

Vanuit bydraes deur die psigologie is dit veral Enright (1991:123-152) wat 'n besonder treffende konseptuele raamwerk vir die fasilitering van vergifnis verskaf binne enige konteks. Die verwonde word deur 'n proses gelei wat begin by die konfrontering van woede, 'n geleidelike oorgang na die gewaarwording van die oortreding, die besluit om te vergewe, en uiteindelik empatie vir die oortreder. 
Enright, Freedman en Rique (1998:53) verskaf 'n uitgebreide weergawe van die oorspronklike stappe en die verwysings in elke stap is prototipiese voorbeelde van die bespreking van die betrokke stap. Volgens Enright en Reed (2007:1) is hierdie stappe padaanwysers. Die sielkundige veranderlikes betrokke by die proses kan as volg opgesom word.

Die ontblotingsfase: Tydens hierdie fase word die woede geïdentifiseer en die sielkundige verdedigingsmeganismes ondersoek soos volg:

- Konfronteer die woede ter vrystelling daarvan, sodat 'n helingsproses kan begin. Erken skaamte, veral as selfvergifnis nodig is. Die belydenis van die verwonde se eie skuld aan die situasie is ' $n$ belangrike stap in selfvergifnis. Selfvergifnis in hierdie konteks is nodig voordat vergifnis kan plaasvind. Besef dat die fokus op die wond en die situasie wat die wond veroorsaak het, emosioneel dreinerend kan wees.

- Besef dat die situasie of daad wat die wond veroorsaak het herhaaldelik in die gedagtes van die verwonde herspeel kan word.

- Die verwonde besef en erken die eie ongelukkige staat, wat swak mag vergelyk met die relatief gemaklike posisie van die oortreder.

- Die verwonde erken en aanvaar dat die oortreder se daad kan lei tot ' $n$ permanente en negatiewe kentering by die oortreder. Die verwonde kom tot die gevolgtrekking dat die lewe nie noodwendig regverdig is nie.

Die besluitnemingsfase: In hierdie fase word die besluit om te vergewe gemaak en die verwonde persoon:

- besef dat die vorige konvensionele probleemoplossing strategieë nie noodwendig effektief was nie

- is bereidwillig om vergifnis as moontlike opsie te ondersoek

- besluit om die oortreder te vergewe

- begin die oortreder se daad in konteks te beskou deur in dié se skoene te gaan staan.

Die werksfase: Hier word aan vergifnis gewerk wat die volgende tot gevolg het:

- Daar ontwikkel empatie vir die oortreder.

- 'n Gevoel van erbarming ontstaan teenoor die oortreder.

- Aanvaarding en absorbering van die pyn van die verwonding word teweeggebring.

- Hierop volg 'n soeke na die betekenis van die lyding vir die self en andere.

Die verdiepingsfase: In hierdie fase word vryheid van emosionele gebondenheid ontdek deur middel van:

- Die verwonde besef dat hul andere se vergifnis in die verlede nodig gehad het.

- Die verwonde besef dat elke mens deel mag vorm van 'n interpersoonlike ondersteuningsnetwerk.

- 'n Nuwe sin vir die lewe ontwikkel asook 'n besef dat dit ontstaan het vanuit die verwonding.

- Dit lei tot 'n gewaarwording van afnemende negatiewe affek, en moontlik positiewe affek teenoor die oortreder, en 'n gewaarwording van interne emosionele bevryding.

\section{Gemeenskaplike temas van die proses van vergifnis}

Sells en Hargraves (1998:28) het bevind dat sekere gemeenskaplike temas voorkom in teorieë oor die proses van vergifnis, naamlik fisiese en/of emosionele pyn, ' $n$ gefragmenteerde verhouding, die voorkoming van die voortsetting van pyn, laat vaar van die negatiewe aspek van die emosies en vergelding via 'n kognitiewe proses en 'n heronderhandeling van die verhouding. McCullough en Worthington (1994:2-14) waarsku egter dat die aanname dat alle mense dieselfde vergifnisprosesmodel behoort te gebruik riskant is, en dat modelle individuele verskille in ag behoort te neem. Hul aanbeveling is dat vergifnisprosesmodelle bruikbaar is in die opvoeding van terapeute oor hoe om vergifnis te fasiliteer en hoe om kliënte daarop voor te berei dat vergifnis 'n proses is. Die essensie van die aspek van vergifnis binne die pastorale gesprek is die element van hoop, as basiese menslike behoefte verwant aan Godgeskapenheid (Tan 2011:329). Beide Moltmann (1993:19, 42, 133) en Louw (2000:459) beklemtoon die eskatologiese dimensie van hierdie hoop in essensie gebore vanuit geloof, wat die beradene tot nuwe geloofshorisonne begelei en 'n dieper sinsdimensie aan die lewenswandel verleen.

\section{Die terapeutiese waarde van vergifnis Inleiding}

Di Blasio en Proctor (1993:179) het bevind dat die gebruik van vergifnis in terapie heel dikwels betekenisvol korreleer met die ontvanklikheid van die terapeut vir die godsdienstige opvattings van die kliënt. Hulle kom tot die gevolgtrekking dat terapeute moontlik ongemaklik is met tegnieke wat 'n fenomeen gebruik wat verband hou met godsdiens.

\section{Riglyne vir die gebruik van vergifnis in terapie}

West (2001:421) beveel die volgende riglyne aan in die lig van sy oorsig oor navorsing rakende die gebruik van vergifnis in terapie:

- Ware vergifnis hou gesondheidsvoordele in vir diegene wat vergewe.

- Alhoewel vergifnis as terapeutiese hulpmiddel voordelig is, behoort dit altyd met sensitiwiteit aangewend te word.

- Vergifnis is 'n proses wat nie noodwendig 'n einde het nie, en wat vir sommige nooit begin nie.

- Tydigheid is belangrik in die gebruik van vergifnis in terapie.

- Dit mag nodig word om deur woede, haat, seer en vrees te werk voordat ware vergifnis moontlik is.

- Vergifnis is nie gelykstaande aan versoening nie, alhoewel dit daartoe kan lei.

- Vergifnis mag empatie insluit by die verwonde wat wel vergifnis toon.

- Die beradene moet baat vind by die daad van vergifnis, ongeag of dit vergifnis van ander of selfvergifnis behels. 


\section{Die toepassing van vergifnis as terapeutiese hulpmiddel by die getraumatiseerde}

Verskeie navorsers het bevind dat die vermoë om te kan vergeef ' $n$ belangrike invloed het op simptome van veral verwondes wat gediagnoseer is met posttraumatiese stresversteuring (PTSV). Orcutt, Pickett en Pope (2005:1020) het byvoorbeeld bevind dat ' $n$ vergifnisrespons tot ' $n$ traumatiese gebeurtenis negatief korreleer met die mate waartoe PTSV-simptome voorkom by verwondes. Hierteenoor is bevind dat ' $\mathrm{n}$ respons wat die aspek van verwonding probeer vermy (fobiese vermyding) deur te weier om daaraan te dink of dit in die geheue op te roep, positief gekorreleer is met sodanige simptome. Hierdie korrelasie word bevestig deur Johnston (2007:37) wat bevind het dat daar minder PTSV-simptome by seksueel getraumatiseerde verwondes voorkom indien daar bewustelike vergifnis van die oortreder is. Snyder en Heinze (2005:436) het bevind dat vergifnis ' $n$ invloed het op die voorkoms van PTSVsimptome by die verwonde wat as kind seksueel misbruik is.

Vergifnis stel die verwonde vry van skuld, hartseer, skaamte en woede weens onreg, verborge haat en bitterheid. Dit voorkom die ontwikkeling van langdurige toksiese emosies wat lewensbagasie word, wat die verwonde emosioneel en fisies siek sou kon maak (Stoop \& Masteller 1991:247-252; Kotze 2008:147).

\section{Die rol van geregtigheid in die genesingsproses}

\section{Leemtes van vergeldende geregtigheid}

Gedurende die afgelope aantal jare oorheers die debat rondom 'herstellende geregtigheid' en die meriete daarvan die Suid-Afrikaanse en internasionale navorsing oor die reg. Binne die Suid-Afrikaanse konteks is die Kommissie vir Waarheid en Versoening 'n sprekende voorbeeld van herstellende geregtigheid. Regstelsels het tradisioneel hoofsaaklik gefokus op 'vergeldende geregtigheid' as 'n manier om oortreders van die wet te straf sonder om die slagoffer van die oortreding in ag te neem. Daarom word die volgende opmerking tereg gemaak:

Daar word nie altyd rekening gehou met die 'wond' wat veroorsaak word deur misdaad nie. Die oortreder word na skuldig bevinding gevangenis toe gestuur, nie oor die wond wat hy toegedien het nie, maar omdat hy die wet oortree het. (Van der Westhuizen 2005:345)

\section{Doelwitte van herstellende geregtigheid}

Gegee die toenemende kritiek op vergeldende geregtigheid, het dit' $n$ prioriteit geword om die behoeftes van die slagoffer in die regsproses in ag te neem. Neser (2001:5) som die doelwitte van herstellende geregtigheid soos volg op:

- Om op ' $n$ betekenisvolle manier aandag te gee aan die materiële, finansiële, emosionele en sosiale behoeftes van die slagoffer.

- Om oortreders die geleentheid te gee om verantwoordelikheid vir hul dade te aanvaar.
- Om die betrokkenheid van die gemeenskap te bewerkstellig by pogings ter gemeenskapsbeveiliging.

- Om oortreders suksesvol te herintegreer in die gemeenskap, ter bevordering van die gemeenskap se sekuriteit.

\section{Die terapeutiese waarde van herstellende geregtigheid}

Die debat rondom herstellende reg het nou begin uitkring na die waarde en rol van vergifnis binne hierdie konteks. Skelton en Batley (2008:38) argumenteer dat die doel van herstellende reg nie vergifnis is nie, maar erken tog dat vergifnis en heling natuurlike uitvloeisels van so ' $n$ proses sou kon wees. Plaatjies (2008:283) reken dat vergifnis nooit 'n verwagting behoort te wees vanuit die slagoffer se oogpunt, of afdwingbaar behoort te word nie. Spies (2009:16) bevind dat binne die konteks van die behandeling van slagoffers van bloedskande, herstellende geregtigheid geleenthede skep vir berou en heling.

\section{Die rol van geloof by emosionele genesing van die verwonde}

Daar is ' $n$ groeiende empiriese belangstelling in die verband tussen vergifnis, geloof en genesing (Exline, Yali \& Lobel 1999:365; Kotze 2008:150). Veral van belang vir hierdie bespreking is die sielkundige literatuur se bevindinge rakende hoe die getraumatiseerde persoon God ervaar, asook die sekulêre navorsing se beskouing van Godvervreemding, en die herstel van die verhouding tussen mens en God na trauma. Dit is veral belangrik om daarop te let dat sielkundige terapie daarop gerig is om die getraumatiseerde weer hul normale, premorbiede funksioneringsvlakke te laat bereik binne sy omgewing.

Die meeste persone se beeld van God is dat hy almagtig is (Pargament 1997:294; Foster \& Keating 1992:368). Daarom gebeur dit dat as daar by die gelowige verwonding plaasvind, 'n herevaluering van hierdie verhouding volg. So toon Falsetti et al. (2003:391-398) aan dat ' $n$ mens se geloofsbeskouing kan verander na 'n traumatiese gebeure. Ganje-Fling en McCarthy (1996:257) argumenteer dat, onderwyl die sielkundige ontwikkeling by seksueel misbruikte kinders begin stagneer tydens die ouderdom van seksuele misbruik, hul geestelike ontwikkeling terselfdertyd ook negatief beïnvloed word. Geestelike wantroue en vertwyfeling is algemeen by hierdie groep getraumatiseerdes.

Hugo (2006:88) bevestig Falsetti et al. (2003:391-398) se waarneming ten opsigte van die belang van die pastorale hulpverlening met die fokus op die lewensbetekeniskomponent teenoor die getraumatiseerde. Dit geskied na afloop van sielkundige stabilisasie, en word pastoraal hanteer as deel van die rol van herintegrasie binne die gemeenskap en geloofsgemeenskap ter ondersteuning en herstel op die lange duur. Arterburn (2005:167-189) fokus ook sterk op laasgenoemde aspek, hoewel hy dit as ' $n$ ingesteldheid van diensbaarheid aanbeveel. Gegee 
Hugo (2004:65-71) se voorstel van die neuro-sielkundige model as toepaslike behandelingsriglyn met inbegrip van beide die neurobiologiese en sielkundige aspekte van trauma, waarsku Newberg en Waldman (2010:53) teen die ontoepaslike aanwending van 'n geestelike invalshoek daar ' $n$ vreesgebaseerde, godsdienstige raamwerk selfs simptome kan opwek wat PTSV-simptome mag naboots, en die persoon teendoeltreffend mag laat reageer op behandeling deurdat verhoogde angsvlakke as resultaat mag manifesteer. Hugo (2004:74; 2006:89) identifiseer tereg ook dat 'n gebrek aan kliniese kennis, vaardighede en insigte by pastorale en geestelike beraders in hulpverlening aan die getraumatiseerde deur toerusting en opleiding aangespreek behoort te word. Tog kwalifiseer Hugo (2006:89) hierdie groep beraders as bevoeg om die geestelike vraagstukke wat trauma na vore bring aan te spreek. Gegee Newberg en Waldman (2010:53) se beklemtoning van empatiese omsigtigheid, sou dit belangrik wees dat kliniese terapeute in dieselfde mate die belang van geestelike en Skrifgerigte toerusting identifiseer alvorens hul die geestelike aspek van trauma aanspreek met die betrokke persone. Louw (2000:4-6) beskou die teologiese reflektering as inleidend tot hierdie pastorale proses gerig op transformasie, geestelike ontwikkeling en die navolging van Christus. Die genesingsdimensie is volgens hom uiteindelik gesetel in die klimaktiese vervulling van die evangelie en hy sluit dit alles in onder die benaming van promissioterapie.

Exline et al. (1999:365-379) het empiries bevind, dat die onvermoë om te aanvaar dat God nie te blameer is nie na ' $n$ pynlike ondervinding, lei tot angstigheid en depressie, asook dat vervreemding van God en woede die meeste bydra tot die onvermoë om te vergewe. Newberg en Waldman (2010:19-20) identifiseer woede tereg as die mens se grootste vyand aangesien dit gesonde breinfunksionering onderbreek, en hulle beklemtoon dan ook die krag en invloed en uitlewing van geloof as wapen daarteen. Arterburn (2005:119) waarsku daarteen dat God se afrekening met die oortreder as 'n voorvereiste gestel word (by die getraumatiseerde) vir 'n besluit tot vergifnis en wapenstilstand, en bespeur erge bitterheid en wraak in sodanige wilsbesluit. Volgens Kotze (2008:194-196) bestaan die moontlikheid dat vir diegene wat in God glo, uiteindelike herstel gekoppel is aan 'n terapeutiese proses gefokus op die prosessering van gevoelens van woede en bitterheid teenoor God weens die getraumatiseerde se begrip van God as Almagtige Persoon wat ten volle in beheer is. Nadat daar in terapie by die seer agter die woede uitgekom kon word, en die verwonde sy of haar bitterheid teenoor God kon bely, volg genesing en herstel.

Verdere navorsing het die verband bevestig tussen gebed enersyds, en fisiese en psigiese genesing asook traumaverwante herstel andersyds. Geloofsbeoefening deur middel van 'n geestelike roetine en gebed, kerklidmaatskap, groepsgebed en sosiale ondersteuning binne 'n geestelike konteks, word toenemend deur medici aangemoedig om spanning en angs verwant aan fisiese en emosionele trauma na afloop van mediese intervensie teë te werk. Die elemente van hoop en positiewe denke toon ' $n$ positiewe korrelasie met geloof en geestelike hernuwing na trauma (Hillman 2002: 272; Courtois et al. 2009:214; Koenig 2008:54).
Kotze (2008:195) het bevind dat trauma gepaard gaan met spesifieke verliese en dat die proses van vergifnis op weg na genesing, gekompliseer word indien die rouproses nie plaasgevind het nie. Skok en ontkenning, woede, depressie, onderhandeling, afhandeling en aanvaarding kenmerk hierdie proses - hierna kan genesing begin realiseer. Verder het Kotze (2008:213) tot die gevolgtrekking gekom dat die verwonde die oortreder slegs kan vergewe indien daar 'n besef is dat God in die eerste plek reeds hul oortredinge vergewe het. God se vergifnis verskaf die basis vir die verwonde se bereidheid om die oortreder te vergewe.

Sigmund (2003:221-229) konstateer dat, gegee die geestelike komponent van die kontinuum van reaksies by die verwonde, die pasiënt beslis kan baat by 'n geestelike assessering. ' $n$ Studie uitgevoer deur Falsetti et al. (2003:391-397) het bevind dat daar ' $n$ positiewe korrelasie bestaan tussen veelvuldige trauma en verhoogde eksistensiële angs. Op grond van die resultate van hierdie studie lewer hy dan ook 'n pleidooi vir die insluiting van die geestelike komponent van menswees in die onderskeie hulpprogramme binne die psigologie ter heling van die getraumatiseerde. Ferreira (2010) wat as sielkundige sy $\mathrm{PhD}$ verwerf het in pastorale berading, se benadering in sy proefskrif dien dan ook as voorbeeld van 'n moontlike model ter bereiking van hierdie oogmerk, wanneer hy met die positiewe sielkunde as vertrekpunt belangrike merkers in hierdie verband uitspel.

\section{Gevolgtrekkinge en riglyne}

Vanuit bovermelde navorsing sou die volgende riglyne met betrekking tot die begeleiding van die emosioneel verwonde persoon in die breë geformuleer kan word:

- Dit het geblyk dat daar die afgelope dekade al meer erkenning gegee is deur psigologiese asook sommige mediese navorsers betreffende die feit dat trauma die fisiese, psigiese, sosiale, kognitiewe en geestelike aspekte van die mens verwond, en dat terapie as sodanig op al hierdie aspekte moet fokus met die oog op volle heling.

- Vergifnis dien as 'n belangrike riglyn en word as 'n pertinente, individuspesifieke aspek binne die terapeutiese genesingsproses bevestig vanuit navorsing op die terreine van verskeie grenswetenskappe.

- Dit het verder geblyk dat daar 'n positiewe korrelasie is tussen selfvergifnis, vergifnis en fisiese genesing, veral in geval van seksuele molestering - ook hierdie aspek kan as ' $n$ belangrike merker dien tydens die begeleidingsproses.

- 'n Volgende riglyn het geblyk verband te hou met die feit dat hantering van woede en bitterheid teenoor God weens die trauma, die korrekte begrip van God na aanleiding van trauma en asimptomatiese funksionering sterk verbande toon. Dit het geblyk dat bitterheid en woede teenoor God na die belewenis van trauma, dikwels tot die ontwikkeling van psigiatriese simptome lei en dan ook kenmerkend is van angssteurnis. Met die nodige begeleiding kan hierdie woede egter gefasiliteer word, kan die simptome afplat, en kan die persoon selfs in ' $n$ herstelde of nuwe verhouding tot God tree. 
- Laastens het geblyk dat daar 'n sterk verband bestaan tussen die genesing van fisiese en psigiese trauma, vergifnis van die oortreder, en 'n herstelde toewyding aan en geloof in God. Vir pastorale beraders is hierdie aspek inderdaad ' $n$ belangrike merker om ingedagte te hou.

In die hantering van bovermelde aspekte is verskeie modelle ter begeleiding van die getraumatiseerde persoon aan die orde gestel, met verskillende grade van aanbevole of bewese sukses. In die genesing van die verwonde is veral drie aspekte as primêr beklemtoon: die verlening van hoop, die skep van 'n veilige, herstellende belewenis, en 'n gesonde verhoudingsraamwerk wat die ontwikkeling van 'n veilige, bevestigende en toepaslike verhouding tussen die terapeut en verwonde impliseer.

\section{Literatuurverwysings}

Al-Mabuk, R.H., Enright, R.D. \& Cardis, P.A., 1995, 'Forgiveness education with parentally love-deprived late adolescents', Journal of Moral Education 24(4), 427 444. http://dx.doi.org/10.1080/0305724950240405

American Psychiatric Association, 2007, Diagnostic and statistical manual of mental disorders, (DSM-IV-TR), 4th edn., American Psychiatric Association, Arlington.

Arterburn, S., 2005, Healing is a choice. Ten decisions that will transform your life and ten lies that can prevent you from making them, Thomas Nelson, Inc., Nashville.

Black, D., Newman, M., Harris-Hendriks, J. \& Mezcy, G. (eds.), 1997, Psychological trauma: A developmental approach, Gaskell Publishers, London.

Borris, E.R., 2003, The healing power of forgiveness:, The Institute for Multi-Track Diplomacy, Occasional paper, no. 10, Washington, viewed 26 July 2009, from http://imtd.org/imtd/OP10

Carroll, E.M. \& Foy, D.W., 1992, 'Assessment and treatment of combat-related posttraumatic stress disorder in a medical center setting', in D.W. Foy (ed.), Treating PTSD: Cognitive-behavioral strategies, pp. 39-68, Guilford Press, New York.

Chambless, D.L., Baker, M.J., Baucom, D.H., Beutler, L.E., Calhoun, K.S. \& Christoph, P., 1998, 'Update on empirically validated therapies II', The Clinical Psychologist 51(1), 3-16.

Coetzer, W., 2006, Trauma berading, Ongepubliseerde bundel, Potchefstroom.

Courtois, C.A., Ford, J.D., Herman, J.L. \& Van der Kolk, B., 2009, Treating complex traumatic stress disorders: An evidence-based guide, Guilford Press, New York.

Decker, L., 1993, 'Beliefs, posttraumatic stress disorder, and mysticism', Journal of Humanistic Psychology 33, 15-32. http://dx.doi.org/10.1177/00221678930334003

Denton, R.T. \& Martin, M.W., 1998, 'Defining forgiveness: An empirical exploration of process and role', The American Journal of Family Therapy 26(7), 281-292. http:// dx.doi.org/10.1080/01926189808251107

Di Blasio, F.A. \& Proctor, J.H., 1993, 'Therapists and the Clinical Use of Forgiveness', The American Journal of Family Therapy 21, 175-184. http://dx.doi. org/10.1080/01926189308250915

Donahue, M.J., 1985, 'Intrinsic religiousness: Review and meta-analysis', Journal of Personality and Social Psychology 48, 400-419. http://dx.doi.org/10.1037/00223514.48.2.400

Enright, R.D. \& The Human Development Study Group, 1991, 'The moral development of forgiveness', in W. Kurtines \& J. Gewirtz (eds.), Handbook of moral behavior and development, pp. 123-150, Erlbaum, Hillsdale, New Jersey.
del

Enright, R.D., Freedman, S. \& Rique, J., 1998, 'The psychology of interpersonal forgiveness', in R.D. Enright \& J. North (eds.), Exploring forgiveness, pp. 46-62, The University of Wisconsin Press, Madison.

Enright, R.D. \& Reed, G., 2007, Process model, viewed 03 November 2009, from www. forgiving.org.

Exline, J.J., Yali, A.M. \& Lobel, M., 1999, 'When God disappoints: Difficulty forgiving God and its role in negative emotion', Journal of Health Psychology 4, 365-379. http://dx.doi.org/10.1177/135910539900400306, PMid:22021604

Falsetti, S.A., Resick, P.A. \& Davis, J.L., 2003, 'Changes in religious beliefs following trauma', Journal of Traumatic Stress 16(4), 391-398. http://dx.doi. org/10.1023/A:1024422220163, PMid:12895022

Ferch, S.R., 1998, 'Intentional forgiving as a counseling intervention', Journal of Counseling and Development 76(3), 261-270. http://dx.doi.org/10.1002/j.15566676.1998.tb02541.x

Ferreira, J.L., 2010, 'Practical wisdom as executive virtue for positive psychology: A pastoral-theological evaluation', PhD thesis, Dept. of Practical Theology, NorthWest University, Potchefstroom.

Foa, E.B. \& Rothbaum, B.O., 1998, Treating the trauma of rape: Cognitive-behaviora therapy for PTSD, Guilford Press, New York.

Foa, E.B., Keane, T.M. \& Friedman, M.J., 2000, Effective treatments for PTSD: Practice guidelines of the International Society for Traumatic Stress Studies, Guilford Press, New York.
Foa, E.B., Chrestman, K.R. \& Gilboa-Schechtman, E., 2008, Prolonged Exposure Therapy for Adolescents with PTSD Emotional Processing of Traumatic Experiences: A Therapist Guide, Oxford University Press, New York.

Foster, R.A. \& Keating, J.P, 1992, 'Measuring androcentrism in the western God concept', Journal for the Scientific Study of Religion 31, 366-375. http://dx.doi. org/10.2307/1387128

Ganje-Fling, M.A. \& McCarthy, P., 1996, 'Impact of Childhood Sexual Abuse on Client Spiritual Development: Counseling Implications', Journal of Counseling and Development 74(3), 253-258. http://dx.doi.org/10.1002/j.1556-6676.1996. tb01861.x

Hargrave, T.D., 1994, Families and forgiveness-healing wounds in the intergenerationa family, Brunner/Mazel Publishers, Levittown.

Hatter, M., 2007, 'EMDR: A Portrait of the mind-body connection', paper presented at the AACC International Conference, Nashville, Tennessee, 14 September.

Herman, J.L., 1997, Trauma and recovery, Basic Books, New York.

Herman, J.L., 2001, Trauma and recovery from domestic abuse to political terror, Pandora, London.

Heystek, P.H., 2000, "n Prakties-teologiese ondersoek van die "mekaar"-opdragte in die Corpus Pualinum met die oog op die kerklike geloofsgemeenskap', ThD tesis, Dept. Teologie, Noord-Wes Potchefstroom, Suid-Afrika.

Hillman, J.L., 2002, Crisis Intervention and trauma. New approaches to evidence-based practice, Plenum Publishers, New York. http://dx.doi.org/10.1007/978-1-4615 0771-0

Hugo, C.J., 2004, 'Pastoral therapy/counseling for post-traumatic stress: A neuropsychological perspective, Part 1', Praktiese Teologie in Suid-Afrika 19(1), 54-76.

Hugo, C.J., 2006, 'Pastoral therapy for post-traumatic stress: A neuropsychological perspective on beliefs, spirituality and meaning', Praktiese Teologie in Suid-Afrika 21(3), 86-104

Hugo, C.J., 2008, 'From trauma support to pastoral care for survivors of trauma: A model of pastoral care', Praktiese Teologie in Suid-Afrika 23(3), 107-126.

Johnston, S.K., 2007, 'The affects of forgiveness on the symptoms of posttraumatic stress disorder as a result of sexual trauma', MA thesis, University of WisconsinWhitewater, viewed 13 September 2009, from http://minds.wisconsin.edu/ handle/1793/11631

Kaplan, B.J. \& Kaplan, V.A., 2007, Kaplan \& Sadock's Synopsis of Psychiatry. Behaviora Sciences/Clinical Psychiatry, 10th edn., Williams and Wilkins, Lippincott, Philadelphia, PA

Klevberg, K., 2005, 'The spiritual costs of being in combat. The military chaplain's role in PTSD-work', Pacem 1, 1-12.

Koenig, H.G., 2008, Medicine, Religion, and Health: Where Science and Spirituality Meet, Templeton Press, West Conshohocken.

Kotze, H.P., 2008, 'Die belangrikheid van die stappe van rou en vergifnis in die herstelproses van die emosioneel verwonde persoon - ' $n$ pastorale studie', PhD tesis, Dept. Teologie, Noord-Wes Universiteit, Potchefstroom, Suid-Afrika.

Leichsenring, F., Salzer, S., Jaeger, U., Kächele, H., Kreische, R., Leweke, F. et al., 2009, 'Shortterm psychodynamic psychotherapy and cognitive-behavioral therapy in generalized anxiety disorder: a randomized, controlled trial', American Journal of Psychiatry 166, 875-881. http://dx.doi.org/10.1176/appi.ajp.2009.09030441, PMid:19570931

Louw, D.J., 2000, A pastoral hermeneutics of care and encounter, Lux Verbi, Wellington.

Lynch, J.J., 1985, The Broken Heart. The Medical Consequences Of Loneliness, Basic Books Inc. Publishers, New York.

Matsakis, A., 1996, I can't get over it. A handbook for trauma survivors, 2nd edn., New Harbinger, Oakland.

Matthews, J.A. \& Chu, J.A, 1997, 'Psychodynamic therapy for patients with early childhood trauma', in P.S. Appelbaum, L.A. Uyehara \& M.R. Elin (eds.), Trauma and Memory: Clinical and Legal Controversies, pp. 316-343, Oxford University and Memory: Clin

McCullough, M. \& Worthington, E., 1994, 'Models of interpersonal forgiveness and their applications to counseling: review and critique', Counseling Values 39, 2-14. http://dx.doi.org/10.1002/j.2161-007X.1994.tb01003.x

Meichenbaum, D., 1977, Cognitive-behavior modification: an integrative approach, Plenum Press, New York.

Moltmann, J., 1993, Theology of hope, Fortress Press, Minneapolis.

Monson, C.M. \& Friedman, M.J., 2006, 'Back to the future of understanding trauma: Implications for cognitive behavioral therapies for trauma', in V.M., Follette \& J.I. Ruzek (eds.), Cognitive behavioral therapies for trauma, pp. 1-13, Guilford Press, New York.

Murray, R.J., 2002, 'The therapeutic use of forgiveness in healing intergenerational pain', Counseling and Values 46, 188-198. http://dx.doi.org/10.1002/j.2161007X.2002.tb00212.x

Newberg, A. \& Waldman, M.R., 2010, How God changes your brain. Breakthrough findings from a leading neuroscientist, Ballantine Books, New York.

Neser, J.J., 2001, 'Restorative justice as reaction to crime: Development and Conceptualisation', Crime Research in South Africa 2(1), 9.

Orcutt, H.K., Pickett, S.M. \& Pope, E.B., 2005, 'Experiential avoidance and forgiveness as mediators in the relation between traumatic interpersonal events and posttraumatic stress disorder symptoms', Journal of Social and Clinical Psychology 24, 1003-1029. http://dx.doi.org/10.1521/jscp.2005.24.7.1003

Pargament, K.I., 1997, The psychology of religion and coping: Theory, research, practice, Guilford, New York. 
Pieterse, H.J.C., 1993, Praktiese teologie as kommunikatiewe handelingsteorie, HSRC, Pretoria.

Plaatjies, M.F., 2008, 'The application of restorative justice in the South African Correctional system', DLitt et Phil thesis, Dept. of Criminology, University of South Africa, Pretoria.

Puffer, K.A., 2007, 'Essential biblical assumptions about human nature: A modes proposal', Journal of Psychology and Christianity 26, 45-56.

Robinson, L.R., 2006, Trauma rehabilitation, Lippincott Williams \& Wilkins, Philadelphia.

SA Federation for Mental Health, 2006, What is mental health?, viewed 13 September 2009, from http://www.safmh.org.za/mentalwell.htm

Scott, M.J. \& Stradling, S.G., 2006, Counseling for Post-traumatic Stress Disorder, 3rd edn., Sage, London.

Sells, J.N. \& Hargrave, T.D., 1998, 'Forgiveness: A review of the theoretical and empirical literature', Journal of Family Therapy 20, 21-36. http://dx.doi. org/10.1111/1467-6427.00066

Shapiro, F., 1989, 'Efficacy of the eye movement desensitization procedure in the treatment of traumatic memories', Journal of Traumatic Stress 2, 199-223. http:// dx.doi.org/10.1002/jts.2490020207

Sigmund, J.A., 2003, 'Spirituality and Trauma: The role of clergy in the treatment of posttraumatic stress disorder', Journal of Religion and Health 42(3), 221-229. http://dx.doi.org/10.1023/A:1024839601896

Skelton, A. \& Batley, M., 2008, 'Restorative justice: a contemporary South African review', Acta Criminologica 21(3), 37-51.

Snyder, C.R. \& Heinze, L.S., 2005, 'Forgiveness as a mediator of the relationship between PTSD and hostility in survivors of childhood abuse', Cognition and Emotion 19(3), 413-431. http://dx.doi.org/10.1080/02699930441000175

Spies, G.M, 2009, 'Restorative justice: a way to support the healing process of a child exposed to incest', Acta Criminologica 22(1), 15-24.

Stoop, D. \& Masteller, J., 1991, Forgiving our parents forgiving ourselves, Servant Publications, Ann Arbor.
Sweeney, D.S., 2011, 'Neurobiological effects of trauma and related treatment considerations', paper presented at the AACC International Conference, Nashville, Tennesee, 22 September

Tan, S., 2011, Counseling and Psychotherapy, Baker Academic, Grand Rapids.

Thompson, L.Y., Snyder, C.R, Hoffman, L., Michael, S.T., Rasmussen, H.N., Billings, L.S. et al., 2005, 'Dispositional forgiveness of self, others, and situations', Journal of Personality 73(2), 313-359. http://dx.doi.org/10.1111/j.14676494.2005.00311.x, PMid:15745433

Van der Westhuizen, B.M., 2005, 'Die uitwerking van oorbevolking binne SuidAfrikaanse gevangenisse op die rehabilitasie van oortreders', DLitt et Phil tesis, Universiteit van Suid-Afrika, Suid-Afrika.

Venter, C., 1996, Uitkringende Liefdesbetoon. Kommunikatiewe handelinge in diens van die onderlinge liefdesgemeenskap in die kerk, HSRC, Pretoria.

West, W., 2001. 'Issues relating to the use of forgiveness in counselling and psychotherapy', British Journal of Guidance \& Counselling 29(4), 415-423. http:// dx.doi.org/10.1080/03069880120085000

Wethington, H.R., Hahn, R.A., Fuqua-Whitley, D.S., Sipe, T.A., Crosby, A.E., Johnson R.L. et al, 2008, 'The effectiveness of interventions to reduce psychological harm from traumatic events among children and adolescents: A systematic review', American Journal of Preventive Medicine 35(3), 287-313. http://dx.doi. org/10.1016/j.amepre.2008.06.024, PMid:18692745

Williams, M.B. \& Sommer, J.F., Jr. (eds.), 2002, Simple and complex PTSD. Strategies for comprehensive treatment in clinical practice, Haworth Press, Binghamton.

Wilson, J.P., Friedman, M.J. \& Lindly, J.D., 2001, Treating psychological trauma and PTSD, Guilford Press, New York.

Worthington, E., 2003, Forgiving and Reconciling. Bridges to wholeness and hope, Inter-Varsity Press, Downers Grove.

World Health Organisation, 2007, What is mental health?, viewed 13 September 2009, from http://www.who.int/features/qa/62/en/index.htm

Wright, H.N., 2003, The new guide to crisis and trauma counselling, Regal Books, Ventura. 